\title{
6. CENOZOIC PLANKTONIC FORAMINIFERS AND HIATUSES ON THE NEW JERSEY SLOPE AND RISE: DEEP SEA DRILLING PROJECT LEG 95, NORTHWEST ATLANTIC ${ }^{1}$
}

\author{
Kenneth G. Miller, Lamont-Doherty Geological Observatory of Columbia University \\ and \\ Malcolm B. Hart, Plymouth Polytechnic ${ }^{2}$
}

\begin{abstract}
At Deep Sea Drilling Project (DSDP) Sites 612 and 613, located on the New Jersey continental slope and upper rise, respectively, we cored thick Cenozoic sections. These sections are interrupted by numerous unconformities, and much of the Oligocene-Miocene section is missing. There are uncertainties in our placement of some planktonic foraminiferal zonal boundaries because of poor preservation in siliceous Eocene chalks, widely spaced (mostly core catcher) samples, and low diversity Neogene assemblages. In addition, the Eocene sections apparently contain insufficient remanent magnetism to obtain a reliable magnetostratigraphic record. Despite this limited stratigraphic control, planktonic foraminiferal biostratigraphy and/or sedimentation rate estimates suggest the following hiatuses: (1) between the Maestrichtian and early Eocene at Site 612; (2) across the early/middle Eocene boundary at both sites; (3) across the middle/late Eocene boundary at Site 612 (between Zone P12-?P14 and the Globigerinatheka semiinvoluta Zone); (4) between the middle Eocene and late Miocene at Site $613 ;(5)$ a possible break between the late Eocene and Oligocene at Site 612; (6) between the earliest Oligocene and late Miocene at Site 612; (7) between the late Pliocene and Pleistocene at Site 612. The timing of some of these erosional events on the New Jersey Transect (e.g., early/middle Eocene, middle/late Eocene, Pliocene/Pleistocene) is similar to that of erosional events noted in northwest Europe, on the Irish margin, and by Vail et al. (1977).
\end{abstract}

\section{INTRODUCTION}

Sites 612 and 613 were drilled during Leg 95 on the New Jersey continental slope and upper rise, respectively, some $110 \mathrm{~km}$ southeast of Alantic City (Fig. 1). These sites were selected to complement Sites 603, 604, and 605 (drilled during Leg 93; van Hinte, Wise, et al., in press) of the New Jersey Transect (see Poag [1985] and Background and Objectives [this volume] for geologic setting of the transect). At Site 612 (1404.3 m present depth; $38^{\circ} 49.21^{\prime} \mathrm{N}, 72^{\circ} 46.43^{\prime} \mathrm{W}$ ), we cored $550.33 \mathrm{~m}$ of Cenozoic sediments; at Site 613 (2323.2 m present depth; $\left.38^{\circ} 46.26^{\prime} \mathrm{N}, 72^{\circ} 31.43^{\prime} \mathrm{W}\right) 581.90 \mathrm{~m}$ of section were cored. More than half of the Cenozoic successions at both sites comprise either siliceous nannofossil chalks or porcellaneous chalks, which yielded poorly preserved foraminifers. Late Neogene planktonic foraminifers are rare or absent in some levels and diversity is low. The successions are difficult to zone accurately (especially in the lower to lower middle Eocene) because much of $\mathrm{Ce}$ nozoic planktonic foraminiferal biostratigraphy relies upon specific and subspecific changes. In addition, our resolution is limited by a wide sampling interval (typically $9.5 \mathrm{~m}$ ); Poag and Low (this volume) corroborated our zonations using closely spaced (typically $10 \mathrm{~cm}$ ) samples across seven unconformities noted in the boreholes.

One of the goals of the New Jersey Transect was to test the timing of erosional events and to compare these

\footnotetext{
${ }^{1}$ Poag, C. W., Watts, A. B., et al., Init. Repts. DSDP, 95: Washington (U.S. Govt. Printing Office).

2 Addresses: (Miller) Lamont-Doherty Geological Observatory of Columbia University, Palisades, NY 10964; (Hart) Department of Environmental Sciences, Plymouth Polytechnic, Drake Circus, Plymouth PL4 8AA, United Kingdom.
}

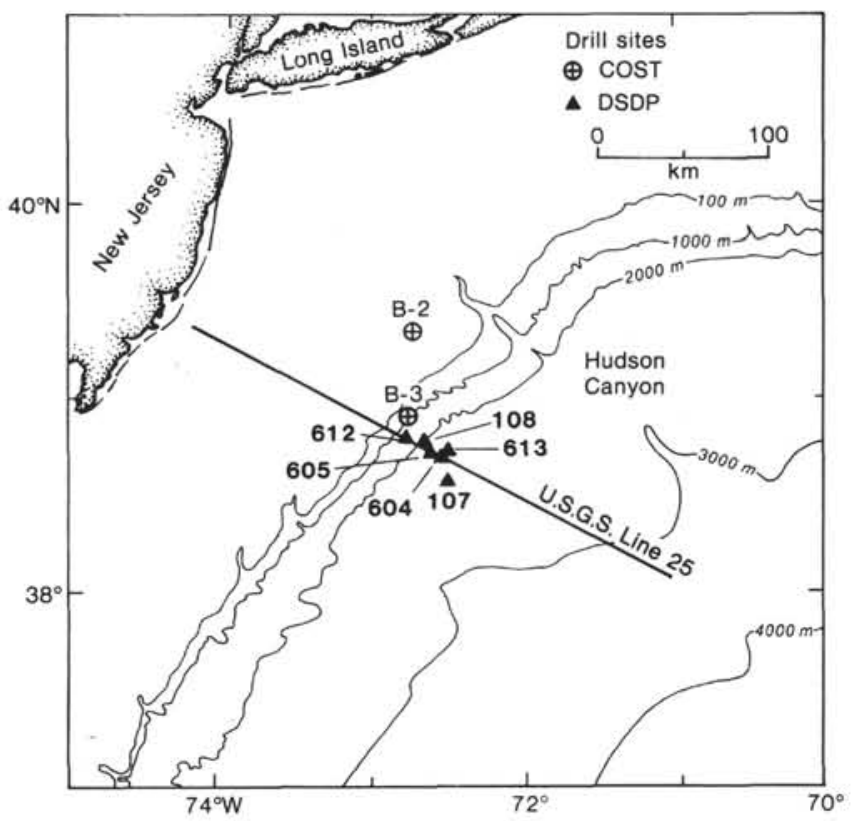

Figure 1. Location map. (COST $=$ Continental Offshore Stratigraphic Test.)

events with the coastal onlap record of Vail et al. (1977). Sections drilled on the transect are interrupted by numerous unconformities caused by downslope erosion (Miller, Mountain, et al., 1985; Poag, 1985; Miller and Katz, this volume; Poag and Low, this volume; Poag and Mountain, this volume). However, two factors limit this test of the "Vail curve": (1) the minimal recovery of Oligocene to middle Miocene sediments, in part because of the placement of Site 612 in a canyon thalweg (Farre, 
1985; Poag and Low, this volume; Poag and Mountain, this volume) and (2) poor preservation of biostratigraphic markers. The goals of this chapter are to revise shipboard biostratigraphic zonations in view of shorebased studies and to evaluate the durations of hiatuses using planktonic foraminifers.

\section{METHODS}

We examined primarily core-catcher samples, supplementing these with samples from certain critical intervals (e.g., near the lower/middle Eocene boundaries, in the upper Eocene at Site 612). Samples were prepared using standard foraminiferal preparation techniques. They were disaggregated gently with dilute hydrogen peroxide, and wet sieved on a $75 \mu \mathrm{m}$ mesh. Samples from the highly siliceous part of the Eocene section did not respond to normal preparation methods and therefore were crushed gently. The dried samples were inspected in the following size fractions: $>500 \mu \mathrm{m}, 500-250 \mu \mathrm{m}, 250-125 \mu \mathrm{m}$, and $125-$ $75 \mu \mathrm{m}$. No quantitative analyses were undertaken in this investigation, since the variable preservation would invalidate intersample comparisons.

We also evaluated the suitability of the Eocene sections at Sites 612 and 613 for magnetostratigraphic analyses. Standard $6 \mathrm{~cm}^{3}$ samples were measured on a ScT cryogenic magnetometer at Lamont-Doherty Geological Observatory. Preliminary measurements suggest that Eocene sections at these sites contain insufficient remanent magnetism to obtain a reliable magnetostratigraphic record.

\section{TAXONOMIC NOTES}

The taxonomic base followed here is a combination of that of Stainforth et al. (1975) and Blow (1979). Blow's finely split taxonomic concepts proved difficult to use, as the poor preservation of Eocene taxa often prevented accurate determinations. No scanning electron microscopy was done because the taxa identified are well known and have been illustrated by previous authors. Original references are cited in the appendix.

\section{ZONAL SCHEMES}

Some confusion surrounds the choice of late Paleocene to middle Eocene zonal schemes. The P-zone scheme for Zones P1-P12 was informally introduced by Berggren (1969); Blow (1979) later completed his (Blow, 1969) P-zone scheme by adding a different set of Zones P1P13. The Berggren (1969) and Blow (1979) schemes are quite different in places (Fig. 2), as noted by Toumarkine and Luterbacher (1985). We used a hybrid zonation based on Blow (1979) and Stainforth et al. (1975) on the ship. Comparisons of our early-middle Eocene zones with the then-unpublished Berggren et al. (1985b) time scale were not entirely correct since the time scale used the informal Berggren Zones P1-P12.

We compiled the best age estimates for first and last occurrences of late Paleocene to middle Eocene planktonic foraminiferal zonal markers (Fig. 2). The ages of most of the markers have been estimated using magnetochronology (Berggren et al., 1985b; and K. Miller, personal observation). We used the P-zones as introduced by Berggren (1969) to draw the zonal boundaries in Figures 3-6; a formal codification of this scheme is in progress (W. A. Berggren, pers. comm., 1986).

We attempted to use the Turborotalia cerroazulensis zonal scheme of Toumarkine and Bolli (1970) for the late Eocene. We had some difficulty in applying this scheme in the middle Eocene because the T. possagnoensis and $T$. pomeroli first appearance levels were anomalously early at Sites 612 and 613 (see Figs. 3, 5); we attribute this to difficulties in determining lineage splitting rather than to poor preservation.

We used the Pliocene zonal schemes of Berggren (1973) and of Blow (1969). We used the Neogene time scale of Berggren et al. (1985a). In general, the late Neogene planktonic foraminiferal assemblages at Sites 612 and 613 were dominated by cool-water taxa and had low species diversity. Therefore, some biostratigraphic zones are difficult to assign because of the absence of marker species.

\section{BIOSTRATIGRAPHY AT SITE 612}

An unconformity is present between the Cretaceous and early Eocene at Site 612 . Core 61 contains middle Maestrichtian planktonic foraminifers (Hart, this volume). We recovered no Paleocene planktonic foraminifers. Core 60 was empty except for the core catcher. Samples $612-60$, CC and $612-59$, CC contain a moderately preserved early Eocene planktonic foraminiferal assemblage: Morozovella subbotinae, Muricoglobigerina soldadoensis soldadoensis, Subbotina linaperta, and S. ?triloculinoides (Fig. 3). Sample 612-60,CC also contained Morozovella aequa and Turborotalia chapmani (Fig. 3); both last appeared in the early $M$. subbotinae Zone of Toumarkine and Luterbacher (1985), suggesting correlation with Zone P6b of Berggren (1969) (Fig. 2).

Our samples from the overlying lower Eocene succession contain poorly preserved planktonic foraminifers. The silicified sediments are difficult to process effectively, and specimens obtained were coated with sediment. Careful processing on shore has hardly improved matters. Recognition of some species is difficult, and some zonal markers (especially species of Morozovella) may have been missed. Some key early Eocene taxa (e.g., $M$. formosa formosa and $M$. formosa gracilis) were not found, making zonal boundaries difficult to position accurately.

In Sample 612-58,CC, M. subbotinae is joined by the first members of the $M$. aragonensis- $M$. lensiformis group, although poor preservation prevents accurately splitting these taxa (Fig. 3). Elsewhere, $M$. lensiformis first appeared in the late M. subbotinae Zone (Toumarkine and Luterbacher, 1985). In Berggren's (1969) scheme, the basal criteria for Zones P7 and P8 were not clear. A revised scheme (W. A. Berggren, pers. comm., 1986), will use the first appearance (FO) of $M$. aragonensis as the Zonal marker for the base of Zone P7 (Fig. 2). Thus, we assign Sample 612-58,CC to the undifferentiated Zones P7-P8, although it could be late Zone P6b (of Berggren, 1969).Sample 612-54,CC apparently contains $M$. aragonensis (Fig. 3), suggesting assignment to Zones P7P8 of Berggren (1969). The assemblage remains unchanged until Sample 612-49,CC, where Pseudohastigerina appears together with Truncorotaloides quetra and Acarinina wilcoxensis (Fig. 3).

Morozovella caucasica first appears in Sample 612$47, \mathrm{CC}$ and ranges up to Sample 612-37,CC (Fig. 3). This taxon first appeared in the late $M$. aragonensis Zone 


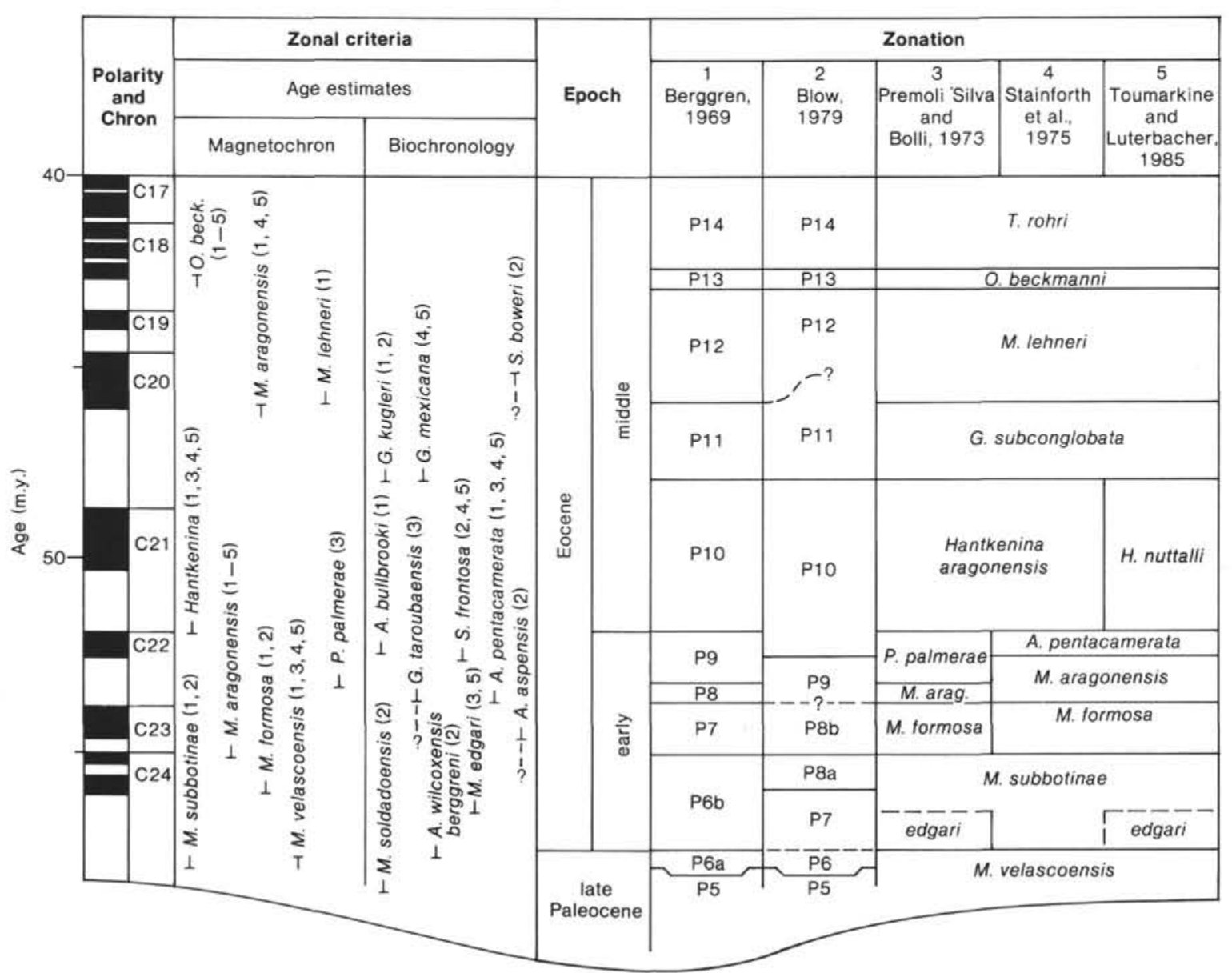

Figure 2. Late Paleocene to middle Eocene planktonic foraminiferal biochronology showing relationships among various zonal schemes. Magnetochronology indicates taxa that have first-order magnetostratigraphic correlations; biochronology indicates taxa whose first or last occurrences were estimated in the absence of magnetostratigraphy. Numbers (1-5) with zonal criteria are cross indexed to zonal schemes: 1 = Berggren, 1969; 2 = Blow, 1979, etc. Magnetochronologic estimates of zonal criteria are after the compilation of Berggren et al. (1985b), except for the first occurrence of $M$. subbotinae, which was magnetochronologically estimated at Site 577.

(Toumarkine and Luterbacher, 1985), suggesting correlation of this interval with Zone P9 (possibly late P8) of Berggren (1969) (Fig. 2). The last appearance of this taxon is thought to approximate the early/middle Eocene boundary (Stainforth et al., 1975), although it may range into the earliest middle Eocene (Toumarkine and Luterbacher, 1985). Samples 612-37-3, 60-64 cm through 612$35, \mathrm{CC}$ are tentatively assigned to middle Eocene Zone P10 of Berggren (1969) (Fig. 2). This assignment is based upon the absence of $M$. caucasica, Globigerinatheka kugleri, and $G$. mexicana, together with the presence of Subbotina frontosa, M. aragonensis, Acarinina bullbrooki, A. broedermani, Truncorotaloides rohri, and Pseudohastigerina wilcoxensis (Fig. 3). Samples 612-37$3,60-64 \mathrm{~cm}$ through $612-21, \mathrm{CC}$, representing approximately $160 \mathrm{~m}$ of sediments, are assigned to the middle Eocene using planktonic foraminifers. Planktonic foraminifers are rare and generally poorly preserved in the lower portion of this section, limiting biostratigraphic resolution. Nevertheless, our shipboard and shore-based studies suggest that Zones P9 and P10 probably are present (Fig. 3).
Despite this relatively complete zonal record, sedimentation rate estimates suggest a major break (about 1-5 m.y.) across the unconformity noted in Core 37 (Fig. 4) (see also Poag and Low, this volume). At least two age (sedimentation rate) models are applicable to the middle Eocene of Site 612 (Fig. 4). One suggests as much as a 5m.y. break at the early/middle Eocene boundary, while the other suggests a break of about $1 \mathrm{~m}$.y. We favor the model with the slower sedimentation rate and shorter hiatus (leftmost line on Fig. 4), based upon our best estimate of the Zone P11/P12 boundary (see below). Nannofossil biostratigraphy also suggests a break across the unconformity in Core 37, from about 50 to $49 \mathrm{Ma}$ (i.e., Zone CP13a is missing) (Site 612 chapter, this volume). However, the nannofossil assignment would place the hiatus within the early middle Eocene. This ambiguity emphasizes the difficulties in estimating the duration of the hiatus represented by the unconformity in Core 37 .

Planktonic foraminiferal biostratigraphic interpretations of the middle Eocene section at Site 612 are uncertain, for Cores 34 to 24 may represent Zones P11 or $\mathrm{P} 12$. In situ Morozovella aragonensis last occurs in Sam- 


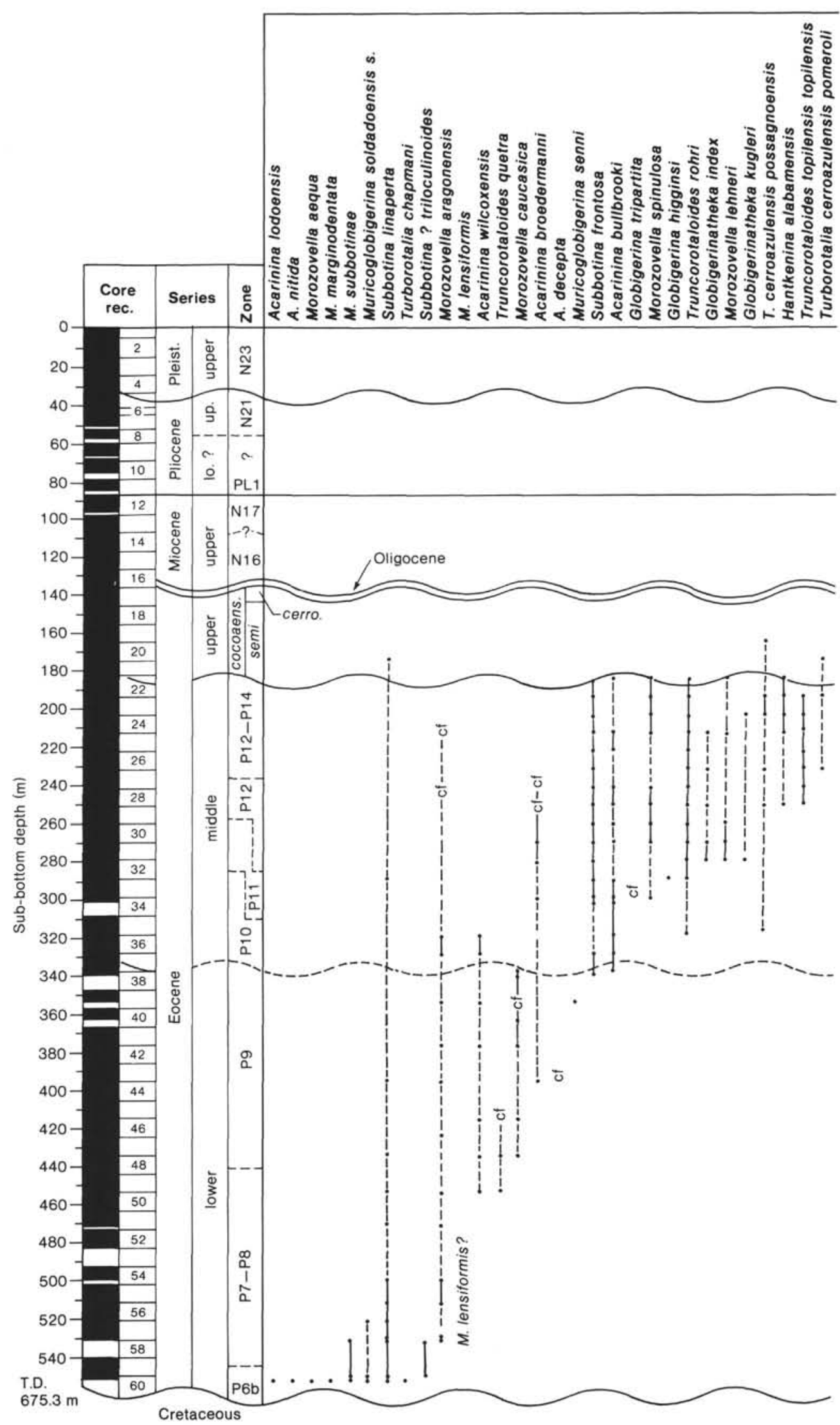

Figure 3. Planktonic foraminiferal range chart for Site 612. Unconformities indicated with wavy lines. Number present: $\mathrm{a}=$ abundant, $\mathrm{c}=$ common, $\mathrm{f}=$ few, $\mathrm{r}=$ rare; preservation: $\mathrm{g}=$ good, $\mathrm{m}=$ moderate, $\mathrm{p}$ $=$ poor. 


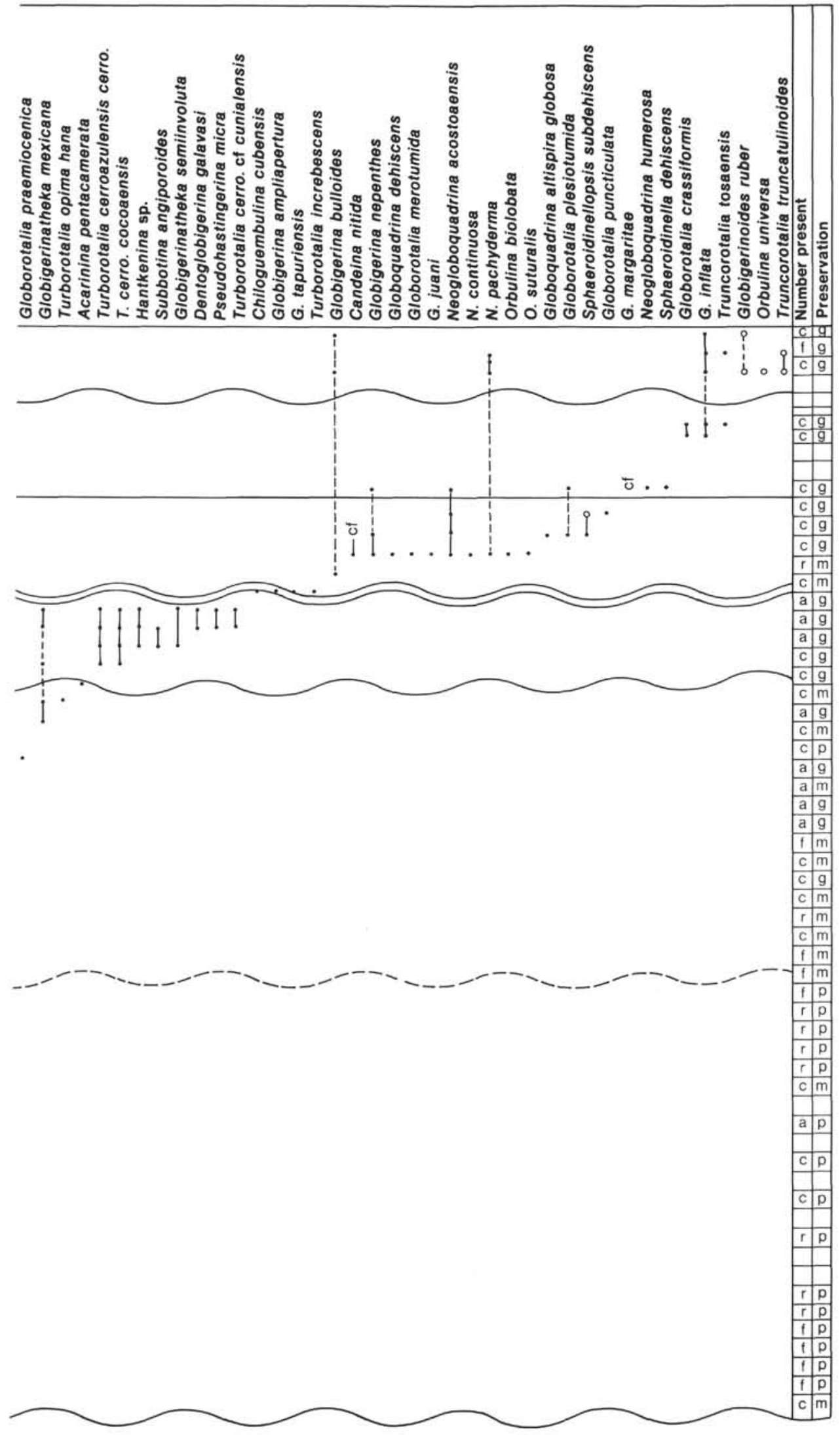

Figure 3 (continued). 


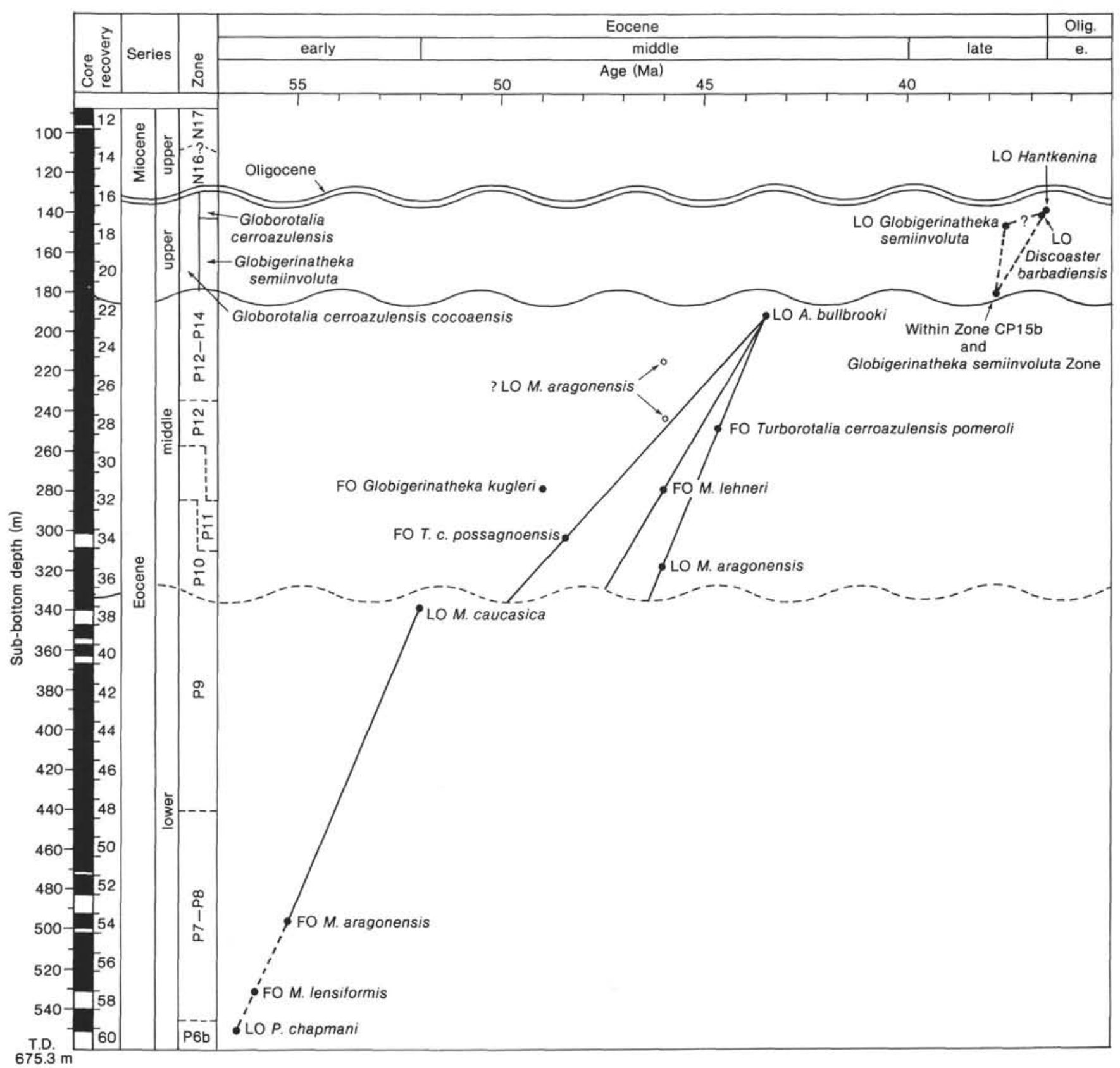

Figure 4. Age-depth plot for the Paleogene of Site 612 showing levels of planktonic foraminiferal datum levels. Datum level ages and chronostratigraphic subdivisions drawn after Berggren et al. $(1985 \mathrm{~b}) . \mathrm{FO}=$ first occurrence; $\mathrm{LO}=$ last occurrence. Wavy lines indicate unconformities and associated hiatuses. Open circles indicate two isolated occurrences of $M$. aragonensis interpreted as reworked.

ple 612-35,CC, with reworked specimens extending into Samples $612-27, C C$ and $612-24, C C$ (Fig. 3). The last occurrence (LO) of $M$. aragonensis is the primary zonal criterion for the base of the M. lehneri Zone of Stainforth et al. (1975) and Toumarkine and Luterbacher (1985), which is correlated with the base of Zone P12 (Fig. 2). However, the zonal marker for the base of Zone P12 (Berggren, 1969), Morozovella lehneri, first appears in Sample 612-31,CC (Fig. 3). This suggests that the last occurrence of $M$. aragonensis in Sample $612-35, C C$ is local or that the true last occurrence was lost because of poor preservation. To further complicate matters, the first appearance (FO) of Globigerinatheka kugleri is al- so in Sample 612-31,CC (Fig. 3); this is the marker for the base of Zone P11 (Berggren, 1969; Blow, 1979). Either Zone P11 is missing, or the FO of G. kugleri may have been delayed because of poor preservation.

Our best estimate is that the Zone P11/P12 boundary is between Samples 612-29,CC and 612-28-6, 150 $\mathrm{cm}$. Acarinina broedermani last appears in Sample 61229, CC (Fig. 3); Blow suggests that this taxon ranges only to the top of Zone P11 (Blow, 1979). Hantkenina alabamensis and Truncorotaloides topilensis first occur in Sample 612-28-6, $150 \mathrm{~cm}$ (Fig. 3). These taxa first occurred elsewhere in Zone P12 of Blow (1979). These relationships suggest that the identification of $M$. lehneri 
in Cores 31-29 may be incorrect or that the FO of this taxon pre-dated the LO of $A$. brodermani and the FO of Hantkenina alabamensis and Truncorotaloides topilensis.

On the basis of the presence of $S$. frontosa, Turborotalia cerroazulensis pomeroli (FO Sample 612-26,CC), Cores 26 through 21 are equivalent to the $T$. c. possagnoensis Zone of Toumarkine and Bolli (1970). The absence of Orbulinoides beckmanni precludes using other schemes for zoning the Core 26-22 interval (see discussion below). The correlation of the LO of $S$. frontosa is debatable, and therefore the relationship of the top of the $T$. c. possagnoensis Zone to other zonations is ambiguous. Toumarkine and Bolli (1970), Stainforth et al. (1975), and Toumarkine and Luterbacher (1985) suggested that $S$. frontosa became extinct at the top of the $M$. lehneri Zone (Zone P12); Blow (1979) suggested that this extinction occurred even earlier (top of his Zone P11). Using the former correlations, Cores 28-21 are part of Zone P12. However, magnetobiostratigraphic correlations (Berggren et al., 1985b) indicate that $S$. frontosa ranged into Magnetochron $\mathrm{C} 18 \mathrm{n}$ (until $42 \mathrm{Ma}$ ), and thus into the 0 . beckmanni Zone and lower portion of the Truncorotaloides rohri Zone (Zones P13-lower P14; Fig. 2). Using this correlation, we suggest that Cores 26-22 are part of late Zone P12 to early Zone P14.

An unconformity representing a 5 m.y. hiatus separates Sample 612-21,CC (Zone P12-P14) from Sample $612-20, C C$ (see also Poag and Low, this volume). The latter contains abundant Turborotalia cerroazulensis cerroazulensis with rare $T . c$. cocoaensis and $T$. c. pomeroli. Forms transitional between $T$. c. cocoaensis and T. $c$. cunialensis occur in Samples 612-18,CC and 612-17,CC (Fig. 3). Therefore, Cores 19 and 20 lie in the T. cerroazulensis cocoaensis Zone of Toumarkine and Bolli (1970, not the T. cerroazulensis Zone of Bolli, 1957). Cores 18 and 17 lie in the upper part of this zone (Toumarkine and Luterbacher, 1985). Globigerinatheka semiinvoluta occurs in Samples 612-19,CC and 612-17,CC (Fig. 3), indicating assignment to the G. semiinvoluta Zone (of Bolli, 1957 and Stainforth et al., 1975). The relationships observed at Site 612 between the T. cerroazulensis cocoaensis Zone and the G. semiinvoluta Zone are the same as observed by Toumarkine and Luterbacher (1985) (Fig. 3).

The Eocene/Oligocene boundary is recognized by the LO of Hantkenina spp. and T. cerroazulensis ssp. (see discussion in Snyder et al., 1984). On the ship we observed this LO in Sample 612-17-4, 60-64 cm. Poag and Low (this volume) note that these taxa range into Sample $612-16, C C$. Thus, there is less than $1 \mathrm{~m}$ of Oligocene sediments present at Site 612 . There may be additional unconformities in the uppermost Eocene section. The section between the LO of G. semiinvoluta and the LO of Hantkenina spp. is only about $1.5 \mathrm{~m}$. Since this interval represents about 1 m.y. (Berggren et al., 1985b), some section must be missing.

An unconformity in Section 16-6 representing a 25m.y. hiatus separates lowermost Oligocene sediments from upper Neogene sediments (see also Poag and Low, this volume). Cores 16 and 15 are assigned to late Miocene
Zone CN7 (Site 612 chapter, this volume). Core 15 contained few planktonic foraminifers; benthic foraminifers indicate a Neogene age based upon the presence of Bulimina striata mexicana. Sample $612-14, C C$ is assigned to the upper Miocene (probably Zone N16); it contains Neogloboquadrina acostaensis, Globoquadrina dehiscens, Globorotalia merotumida/plesiotumida, N. continuosa, and Globigerinoides parkerae (Fig. 3). Sample 612-13,CC is probably late late Miocene (N17) as denoted by the presence of Globigerina nepenthes, G. plesiotumida, Globoquadrina altispira globosa, and $N$. acostaensis (Fig. 3). We noted in the Site 612 chapter that this sample could be earliest Pliocene based upon Sphaeroidinella sp. with a pinhole supplementary aperture. However, nannofossils indicate that Core 13 is late Miocene. Poag and Low (this volume) suggest that an unconformity noted within Core 13 separates lower upper Miocene (Tortonian) from upper upper Miocene (Messinian) strata. Core 12 is indeterminate. Sample $612-11, C C$ contains a Pliocene assemblage (Zone PL1) of Globorotalia cf. margaritae, $N$. acostaensis, $N$. humerosa, and $G$. nepenthes (Fig. 3). Samples 612-10,CC and 612-9,CC are barren of planktonic foraminifers, while Sample $612-8, \mathrm{CC}$ contains a late Pliocene assemblage including Globorotalia crassiformis and G. inflata (Fig. 3). Sample 612-7,CC is assigned to upper Pliocene Zone N21 based upon the presence of T. tosaensis (Fig. 3). Cores 1-4 are Pleistocene based upon the presence of Truncorotalia truncatulinoides (Fig. 3). Sample 612-5,CC contains $T$. crassula without $T$. truncatulinoides. It is assigned to the upper Pliocene, in agreement with the nannofossil evidence (see also Poag and Low, this volume), although Scott (this volume) argues that Cores 5-8 are Pleistocene.

\section{BIOSTRATIGRAPHY OF SITE 613}

Eocene biostratigraphic control at Site 613 is better than at Site 612. Many primary and secondary zonal criteria of Berggren (1969), Stainforth et al. (1975), Blow (1979), and Toumarkine and Luterbacher (1985) are in reasonable agreement at Site 613 . This contrasts with Site 612 , where the expected ranges of many taxa were inverted and we were forced to choose which first occurrences were delayed and which last occurrences were premature.

Cores 53 through 37 represent the lower Eocene recognized using planktonic foraminifers at this site. The Paleocene/Eocene contact was not reached, and it is difficult to assess how much of the lower Eocene was recovered. The lowermost sample recovered (613-52,CC) contains a moderately well preserved planktonic foraminiferal assemblage containing representatives of the $\mathrm{Mo}$ rozovella aragonensis-lensiformis group and $M$. formosa gracilis (Fig. 5). M. marginodentata occurs with these taxa in Samples 613-51,CC to 613-49,CC (Fig. 5). If specimens noted in Samples 613-52,CC to 613-49, CC are $M$. aragonensis, then this interval correlates with Zones P7P8 of Berggren (1969); however, if these specimens belong to $M$. lensiformis, then this interval may represent Zone P6b of Berggren (1969). Toumarkine and Luterbacher (1985) suggested that $M$. marginodentata ranged into the early $M$. formosa Zone (Zone P7 of Berggren, 


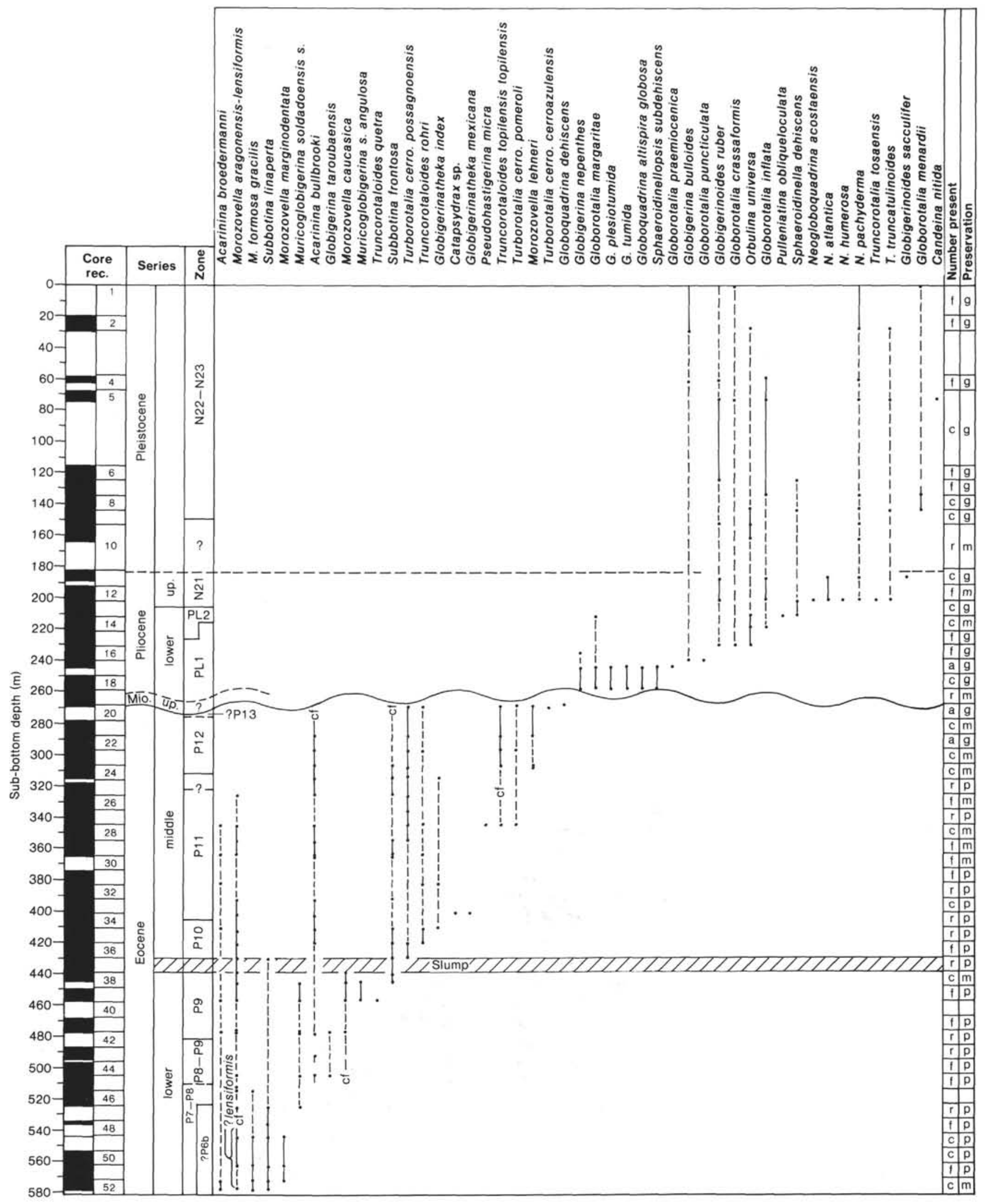

Figure 5. Planktonic foraminiferal range chart for Site 613. Unconformities indicated with wavy lines. Number present: $\mathrm{a}=\mathrm{abundant}, \mathrm{c}=\mathrm{com}$ mon, $\mathrm{f}=$ few, $\mathrm{r}=$ rare; preservation: $\mathrm{g}=$ good, $\mathrm{m}=$ moderate, $\mathrm{p}=$ poor. 
1969). We, therefore, assign this interval to Zones P7P8 (Figs. 5,6).

The interval from Sample $613-48, \mathrm{CC}$ to $613-45, \mathrm{CC}$ is assigned to the later part of Zones P7-P8 (probably P8) of Berggren (1969). This is based upon the absence of $M$. marginodentata, $M$. lensiformis, and $M$. caucasica, together with the presence of well-developed $M$. aragonensis (Fig. 5). M. formosa gracilis last appears at the top of this interval (Fig. 5). Toumarkine and Luterbacher (1985) noted that this taxon became extinct in their $M$. aragonensis Zone (= Zone P9 of Berggren, 1969; Fig. 2), suggesting that the Zone P8/P9 boundary is in Cores 44 or 45 . This is supported by the appearance of forms approaching $A$. bullbrooki (= basal criterion, Zone P9 of Berggren, 1969; Fig. 2) in Samples 613-44,CC and 613-43,CC. Nevertheless, definite $A$. bullbrooki does not appear until Sample 613-42, CC (Fig. 5). Globigerina taroubaensis first appears in Sample 613-44,CC (Fig. 5), suggesting correlation to late Zones P7-P8 of Berggren (Fig. 2). We therefore assign Samples $613-44, C C$ and 613-43, CC to undifferentiated Zone P8-P9 of Berggren (1969).

Samples $613-42, \mathrm{CC}$ to $613-37, \mathrm{CC}$ are assigned to Zone P9 based upon the co-occurrence of $M$. caucasica and A. bullbrooki (Fig. 5). FO Hantkenina spp. cannot be used as a criterion for the base of Zone P10 at Site 613 because of poor preservation of this interval. As at Site 612 , we place the top of Zone P9 and the top of the lower Eocene at the LO of M. caucasica. Truncorotaloides rohri first appears in Sample 613-35,CC (Fig. 5). Convoluted bedding ascribed to slumping occurs in Core 37 and part of Core 36 (Site 613 chapter, this volume). Sediments above this slumped interval are assigned to Zone P10. Therefore, there seems to have been little biostratigraphic break across the lower/middle Eocene boundary, as we observed at Site 612. However, sedimentation rate estimates (Fig. 6) suggest that some section is missing across the lower/middle Eocene unconformity at Site 613, similar to the hiatus inferred at Site 612 . We suggest that a hiatus of about $2 \mathrm{~m}$.y. (from 52 to $50 \mathrm{Ma}$ ) spanned the early/middle Eocene boundary at Site 613.

Low diversity assemblages noted in Samples 613-35,CC and $613-34, C C$ consist only of $M$. aragonensis, $A$. bullbrooki, S. frontosa, T. rohri, T. cerroazulensis possagnoensis (Fig. 5), with the addition of Globigerinatheka index and Acarinina broedermanni in Sample 613-34,CC. Globigerinatheka mexicana first appears in Sample 61333, CC, suggesting that this is the base of Zone P11 (Fig. 5). The FO of $T$. topilensis topilensis and the $\mathrm{LO}$ of $A$.

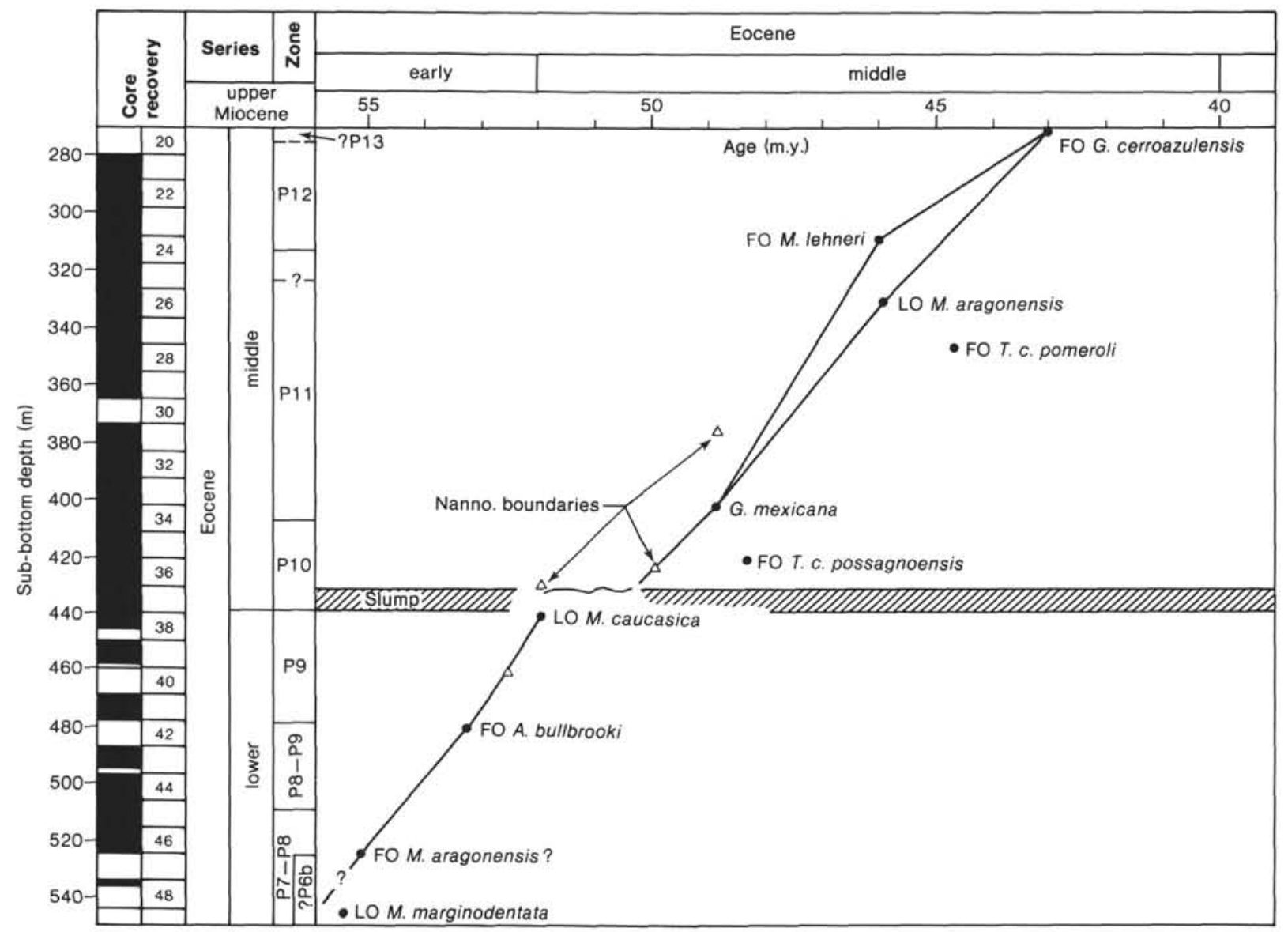

Figure 6. Age-depth plot for the Paleogene of Site 613 showing levels of planktonic foraminiferal datum levels. Datum level ages and chronostratigraphic subdivisions drawn after Berggren et al. $(1985 \mathrm{~b})$. FO = first occurrence; LO = last occurrence. Wavy lines indicate unconformities and associated hiatuses. 
broedermanni are in Sample 613-27,CC (Fig. 5). Morozovella aragonensis disappears above Sample 613-25,CC, indicating the base of the M. lehneri Zone of Stainforth et al. (1975), which should equal the base of Zone P12 (Fig. 2). However, M. lehneri (the base of Zone P12 of Berggren, 1969) (Fig. 2) does not appear until Sample 613-23,CC. Thus, Cores 24 and 25 may be either Zone P11 or P12. Forms approaching Turoborotalia cerroazulensis cerroazulensis were noted in Sample 613$20, \mathrm{CC}$, suggesting that this may correlate with Zones P13-P14 (Toumarkine and Bolli, 1970). An unconformity representing about 37 m.y. occurs between Samples 613-20,CC and 613-19,CC.

Sample 613-19,CC contained only Miocene Globoquadrina dehiscens. Nannofossils indicate that this sample is lower upper Miocene (Site 613 chapter, this volume). Samples 613-18,CC through 613-15,CC are assigned to lower Pliocene Zone PL1, based upon the presence of Globigerina nepenthes, Globoquadrina altispira, Globorotalia margaritae, G. tumida, G. plesiotumida, Sphaeroidinella subdehiscens, and G. puncticulata (Fig. 5). Globorotalia crassaformis appears in Sample 613-15,CC. The zonal assignment of the overlying sample $(613-14, C C)$ is indeterminate, but Sample 613-13,CC contains G. margaritae, S. subdehiscens, and Sphaeroidinella dehiscens (without G. nepenthes), indicative of Zone PL2 (Fig. 5). Upper Pliocene sediments (Zone N21) occur in Sample 613-12, CC as indicated by Truncorotalia tosaensis, G. crassula, G. crassaformis, G. inflata, G. puncticulata, Neogloboquadrina atlantica, $N$. acostaensis, $N$. humerosa, and N. pachyderma (Fig. 5). Abraded specimens of T. truncatulinoides noted in this sample are interpreted as contaminants. Sample 613-11,CC contains G. miocenica, indicative of the late Pliocene. Samples 613-10,CC and 613-9, CC are indeterminate, while the overlying samples $(613-8, C C$ to $613-1, C C)$ contain Pleistocene T. truncatulinoides (Fig. 5).

\section{DISCUSSION}

One of the primary goals of the New Jersey Transect was to document the timing of erosional events on the U.S. Atlantic passive continental margin. We recovered many unconformities at Sites 612 and 613 (Site 612 and 613 chapters, this volume; Poag and Low, this volume). Many of these are associated with long hiatuses, typically greater than $5 \mathrm{~m}$.y. Much of the Oligocene-Miocene section was missing at both sites; prominent hiatuses (>10 m.y.) are associated with the Eocene/Miocene contact at Site 613, the lowermost Oligocene/upper Miocene contact at Site 612, and the Maestrichtian/Eocene contact at Site 612 (Figs. 3,5). We cannot compare these long breaks with any specific event of Vail et al. (1977) or with other records of margin erosion (see Thorne and Watts, 1984 for discussion). Poag and Mountain (this volume) suggest that some of these long breaks may be the result of local erosional events.

Some unconformities have shorter hiatuses. Determination of the amount of time missing (if any) across these unconformities is hampered by uncertainties in planktonic foraminiferal biostratigraphy and by lack of a magnetostratigraphic record at Sites 612 and 613. Nev- ertheless, we have attempted to estimate the amount of time missing across these breaks at Sites 612 and 613.

There are only subtle paleontological breaks associated with the unconformities noted at the lower/middle Eocene boundaries at Sites 612 and 613 . Every planktonic foraminiferal zone is apparently present. Nevertheless, sedimentation rate estimates suggest that hiatuses of as much as 5 and 3 m.y., respectively, may be present at these sites.

Downslope erosion associated with mass-flows (slides, slumps, debris flows, and/or turbidites) caused unconformities and channeling across the lower/middle Eocene boundary at Sites 612 and 613 (Poag and Mountain, this volume). The hiatus at Site 612 is associated with a prominent unconformity noted in the borehole (Poag and Low, this volume). The hiatus at Site 613 is associated with channels filled with slump debris (Poag and Mountain, this volume). The debris filling these channels is locally derived, with no evidence of shallow-water benthic foraminifers (Miller and Katz, this volume). Both sites lay in bathyal water depths at this time (Site 612: about $1000 \mathrm{~m}$; Site 613: about $2000 \mathrm{~m}$; Miller and Katz, this volume). Thus, the erosion that caused these unconformities must be attributed to submarine mass flows; subsequent local slumping filled the channels.

The erosion that occurred near the early/middle Eocene boundaries at Sites 612 and 613 correlates with erosion noted on other margins. Erosion occurred at this time on the Irish margin (Miller, Ostermann, et al., 1985; Poag et al., 1985; Snyder and Waters, 1985), in northwest Europe (Aubry, 1985), and in the Gulf Coast (Hazel et al., 1984). A drop in relative sea level occurred near the early/middle Eocene boundary in New Jersey (Charletta, 1980), Libya (Barr and Berggren, 1981), and California (Berggren and Aubert, 1983). This widespread distribution suggests that a eustatic lowering caused the erosion. One of the major ("type 1") erosional "offlap" events of Vail et al. (1977) occurs at the early/middle Eocene boundary. Our results support their suggestion that a major erosional event occurred near the early/ middle Eocene boundary.

At Sites 612 and 613 , the biostratigraphic zonal assignment of the upper part of the middle Eocene is debatable. We did not observe Orbulinoides beckmanni at either site; thus, Zone $\mathrm{P} 13$ ( $=0$. beckmanni total range zone) is not identifiable (Fig. 2). Luterbacher (1972) reported this taxon from the upper middle Eocene strata at Site 108. However, our examination of material from Site 108 failed to confirm the presence of 0 . beckmanni. This is probably because of the small samples we examined $\left(20 \mathrm{~cm}^{3}\right)$ versus large core catcher samples examined by Luterbacher. We believe that the uppermost middle Eocene strata at Sites 612 and 613 correlate with Zones P12 to earliest P14 (see discussion below). Stratigraphic position also suggests that the top of the middle Eocene strata recovered at Site 612 should be slightly younger than at the top of the middle Eocene at Site 108 (= Zone P13 following Luterbacher, 1972), since the latter can be traced to a level below that at Site 612 .

Jones (1983) and Berggren and Aubry (1984) reported planktonic foraminiferal fauna from the Castle Hay- 
ne Formation, North Carolina which is similar to that of the upper middle Eocene at Sites 612 and 613 (with Hantkenina longispina, Subbotina frontosa, Globorotalia cerroazulensis pomeroli, Acarinina bullbrooki, Truncorotaloides rohri, T. topilensis, Morozovella lehneri, and Globigerinatheka mexicana). Although Jones (1982) originally favored assignment of this fauna to Zones P11P12 of Berggren (1969), later he (1983) and Berggren and Aubry (1984) favored assignment to Zones P12-P13 of Berggren (1969). The primary zonal criterion for Zone P13, 0. beckmanni, is absent from the Castle Hayne Formation. The Castle Hayne Formation (partim) has been assigned to nannofossil Zone NP16 (Berggren and Aubry, 1984), while the upper middle Eocene strata at Sites 612 and 613 have been assigned to Zone CP14a (= late NP16) (Valentine, this volume). The presence of these nannofossil zones supports the correlation to late Zone P12 to early P14. The presence of $S$. frontosa at Sites 612 and 613 and in the Castle Hayne Formation suggests that these strata are 42 m.y. or older (Berggren et al., 1985b). This suggests that:(1) the Castle Hayne Formation (partim) correlates with the uppermost middle Eocene strata at Sites 612 and 613; (2) both are older than about $42 \mathrm{Ma}$, correlating with upper Zone P12 to lower Zone P14; and (3) this late middle Eocene interval represents widespread deposition on the margin from New Jersey (Luterbacher, 1972; Charletta, 1980); to North Carolina (Jones, 1982, 1983; Berggren and Aubry, 1984).

There is a major biostratigraphic gap between the middle Eocene and the late Eocene at Site 612. We estimate that sediments below the unconformity are slightly older than 42 m.y. (see above). Sediments above the unconformity belong to the late $G$. semiinvoluta Zone and the T. cerroazulensis cocaensis Zone (Fig. 3); nannofossils indicate placement in Zone CP15b (Site 612 chapter, this volume). This suggests that sediments above the unconformity are about $37.8 \mathrm{~m}$.y. old (Berggren et al., 1985b). Thus, a hiatus of about $5 \mathrm{~m}$.y. spanned the middle/late Eocene boundary at Site 612. This gap correlates with a similar break noted at Irish margin Site 548 (Miller et al., 1985b; Poag et al., 1985), a possible break in northwest Europe (Aubry, 1985), and an "offlap" event of Vail et al. (1977). A possible break at Site 612 within the late Eocene or between the late Eocene and earliest Oligocene cannot be fully evaluated because of limited biostratigraphic control (Fig. 5). Similarly, possible breaks within the late Miocene at Site 612 (e.g., Poag and Low, this volume) are difficult to evaluate with our widelyspaced samples. A break between the late Pliocene and Pleistocene at Site 612 correlates with an offlap event of Vail et al. (1977); see Poag and Low (this volume) for further discussion.

\section{CONCLUSIONS}

1. Precise placement of planktonic foraminiferal zonal boundaries at Sites 612 and 613 is difficult because of poor preservation in siliceous Eocene chalks, low diversity Neogene assemblages, and widely-spaced samples in certain critical intervals.

2. The Eocene sections at Sites 612 and 613 apparently contain insufficient remanent magnetism to obtain a reliable magnetostratigraphic record.
3. Despite limited stratigraphic control, planktonic foraminiferal biostratigraphy and/or sedimentation rate estimates suggest the following hiatuses:

a. Between the Maestrichtian and early Eocene at Site 612;

b. across the early/middle Eocene boundary at Sites 612 and 613 ;

c. across the middle/late Eocene boundary at Site 612 (between Zone P12-P14 and the G. semiinvoluta Zone);

d. between the middle Eocene and late Miocene at Site 613;

e. possible break between the late Eocene and Oligocene at Site 612;

f. between the lowermost Oligocene and upper Miocene at Site 612; 612 .

g. between the late Pliocene and Pleistocene at Site

The hiatuses at Sites 612 and 613 are represented by physical unconformities noted in the cores (Poag and Low, this volume) and with seismic evidence of erosion (Farre, 1985; Miller, Mountain, et al., 1985; Poag and Mountain, this volume). The timing of some of these erosional events on the New Jersey Transect (e.g., early/ middle Eocene, middle/late Eocene, Pliocene/Pleistocene) is similar to erosional events noted in northwest Europe, the Irish margin, and by Vail et al. (1977). Many of the hiatuses noted are long (e.g., the Eocene/Miocene, Maestrichtian/Eocene breaks), and may have been caused by one or more erosional events.

\section{ACKNOWLEDGMENTS}

We thank W.A. Berggren, M. E. Katz, C. W. Poag, and S. W. Snyder for reviewing the manuscript, the shipboard party for discussions, M. E. Katz for technical assistance, and N. Katz for drafting. Discussions with W. A. Berggren, G. S. Mountain, A. Palmer, C. W. Poag, and P. Valentine were particularly helpful. All paleomagnetic analyses were performed in the laboratory of D. V. Kent (L-DGO). This research was funded by NSF Grant OCE85-00859 (Miller), The Natural Environmental Reasearch Council, and Plymouth Polytechnic (Hart). This is Lamont-Doherty Geological Observatory Contribution Number 4062 .

\section{REFERENCES}

Aubry, M.-P., 1985. Northwestern European Paleogene magnetostratigraphy, biostratigraphy, and paleogeography: calcareous nannofossil evidence. Geology, 13(3):161-224.

Barr, F. T., and Berggren, W. A., 1981. Lower Tertiary biostratigraphy and tectonics of northeastern Libya. In Solem, M., and Busrewil, M.-T. (Eds.), The Geology of Libya (Vol. 1): London (Academic Press), 163-192.

Berggren, W. A., 1969. Rates of evolution in some Cenozoic planktonic foraminifera. Micropaleontology, 15:351-365. 1973. The Pliocene time scale: calibration of planktonic foraminiferal and calcareous nannoplankton zones. Nature, 243(5407): 391-397

Berggren, W. A., and Aubert, J., 1983. Paleogene benthic foraminiferal biostratigraphy and paleobathymetry of the central Coast Ranges of California. In Brabb, E. E. (Ed.), Studies in Tertiary Stratigraphy of the California Coast Ranges. U.S.G.S. Prof. Pap., 1213: 4-21.

Berggren, W. A., and Aubry, M.-P., 1984. Rb-Sr glauconite isochron of the Eocene Castle Hayne Limestone, North Carolina: further discussion. Geol. Soc. Am. Bull., 95:364-370.

Berggren, W. A., Kent, D. V., and Flynn, J., 1985a. Neogene geochronology and chronostratigraphy. In Snelling, N. J. (Ed.), Geochronology and the Geologic Time Scale. Geol. Soc. London Spec. Publ., 10:221-260. 
1985b. Paleogene geochronology and chronostratigraphy. In Snelling, N. J. (Ed.), Geochronology and the Geologic Time Scale. Geol. Soc. London Spec. Publ., 10:141-195.

Blow, W. H., 1969. Late middle Eocene to Recent planktonic foraminiferal biostratigraphy. Proc. First Int. Conf. Plankt. Microfossils, Geneva, 1967, 1:199-422.

1979. The Cainozoic Globigerinida: London (E. J. Brill).

Bolli, H. M., 1957. The genera Globigerina and Globorotalia in the Paleocene-lower Eocene Lizard Springs Formation of Trinidad, B.W.I. Bull. U.S. Natl. Mus., 215:61-81.

Charletta, A. C., 1980. Eocene benthic foraminiferal paleoecology and paleobathymetry of the New Jersey continental margin [unpubl. Ph.D. thesis]. Rutgers, The State University of New Jersey, New Brunswick, N.J.

Farre, J. A., 1985. The importance of mass wasting processes on the continental slope [unpubl. Ph.D. thesis]. Columbia Univ., New York.

Hazel, J. E., Edwards, L. E., and Bybell, L. M., 1984. Significant unconformities and the hiatuses represented by them in the Paleogene of the Atlantic and Gulf Coastal Province. In Schlee, J. S. (Ed.), Interregional Unconformities and Hydrocarbon Accumulation. Am. Assoc. Pet. Geol. Mem., 36:59-66.

Jones, G. D., 1982. Foraminiferal paleontology and geology of lower Claibornian rocks of the inner Coastal Plain of North Carolina [Ph.D. thesis]. University of Delaware, Newark.

1983. Foraminiferal biostratigraphy and depositional history of the middle Eocene rocks of the coastal plain of North Carolina. N.C. Geol. Surv., Spec. Publ., 8:1-80.

Luterbacher, H., 1972. Paleocene and Eocene planktonic foraminifera, Leg XI, Deep Sea Drilling Project. In Hollister, C. D., Ewing, J. I., et al., Init. Repts. DSDP, 11: Washington (U.S. Govt. Printing Office), $547-550$.

Miller, K. G., Mountain, G. S., and Tucholke, B. E., 1985. Oligocene glacioeustasy and erosion on the margins of the North Atlantic. Geology, 13:10-13.

Miller, K. G., Ostermann, D. R., and Curry, W. B., 1985. Late Paleogene (Eocene to Oligocene) benthic foraminiferal oceanography of the Goban Spur region, Deep Sea Drilling Project Leg 80. In Graciansky, P. C. de, Poag, C. W., et al., Init. Repts. DSDP, 80: Washington (U.S. Govt. Printing Office), 505-538.

Poag, C. W., 1985. Cenozoic and upper Cretaceous sedimentary facies and depositional systems of the New Jersey slope and rise. In Poag, C. W. (Ed.), Geologic Evolution of the United States Atlantic Margin: New York, (Van Nostrand Reinhold), pp. 343-365.

Premoli Silva, I., and Bolli, H. M. 1973. Late Gretaceous to Eocene planktonic foraminifera and stratigraphy of Leg 15 sites in the Caribbean Sea. In Edgar, N. T., and Saunders, J. B., et al., Init. Repts.' DSDP, 15: Washington (U.S. Govt. Printing Office), 449547.

Snyder, S. W., Müller, C., and Miller, K. G., 1984. Eocene-Oligocene boundary: biostratigraphic recognition and gradual paleoceanographic change at DSDP Site 549. Geology, 12:112 115.

Snyder, S. W., and Waters, V. J., 1985. Cenozoic planktonic formaminiferal biostratigraphy of the Goban Spur region, DSDP Leg 80. In Graciansky, P. C. de, Poag, C. W., et al., Init. Repts. DSDP, 80: Washington (U.S. Govt. Printing Office), 439-461.

Stainforth, R. M., Lamb, J. L., Luterbacher, H., Beard, J. H., and Jeffords, R. M., 1975. Cenozoic planktonic foraminiferal zonation and characteristics of index fossils. Kansas Univ., Pal. Contr. Art., 62:1-425.

Thorne, J., and Watts, A. B., 1984. Seismic reflectors and unconformities at passive continental margins. Nature, 311(5984):365368.

Toumarkine, M., and Bolli, H. M., 1970. Evolution de Globorotalia cerroazulensis (Cole) dans l'Eocene moyen et superieur de Possagno (Italie). Rev. Micropaleontol., 13(3):131-145.

Toumarkine, M., and Luterbacher, H., 1985. Paleocene and Eocene planktic foraminifera. In Bolli, H. M., Saunders, J. B., PerchNielsen, K. (Eds.), Plankton Stratigraphy: Cambridge (Cambridge Univ. Press), pp. 87-154.

Vail, P. R., Mitchum, R. M., Todd, R. G., Widmier, J. M., Thompson, S., III, Sangree, J. B., Bubb, J. N., and Hatlelid, W. G., 1977. Seismic stratigraphy and global changes of sea level. In Payton, C. E. (Ed.), Seismic Stratigraphy-Applications to Hydrocarbon Exploration. Am. Assoc. Pet. Geol. Mem., 26:49-205. van Hinte, J. E., Wise, W. W., et al., in press. Init. Repts. DSDP, 93: Washington (U.S. Govt. Printing Office).

Date of Initial Receipt: 28 April 1986

Date of Acceptance: 23 June 1986

\section{Species List}

Original citation of taxa recognized in this study. Full references are not listed here, but most may be found in Stainforth et al. (1975). ${ }^{3}$

Acarinina bullbrooki (Bolli)

Globorotalia bullbrooki Bolli, 1957c, p. 167-168, pl. 38, figs. 4-5

Acarinina broedermanni (Cushman and Bermudez)

Globorotalia (Truncorotalia) broedermanni Cushman and Bermudez 1949 , p. 40 , pl. 7 , figs. $22-24$

Acarinina decepta (Martin)

Globigerina decepta Martin, 1943, p. 114, pl. 7, figs. 2a-c.

Acarinina lodoensis (Mallory)

Globorotalia broedermanni lodoensis Mallory, 1959, p. 235, figs. $3 a-c$

Acarinina nitida (Martin)

Globigerina nitida Martin, 1943, p. 115, pl. 7, fig. 1.

Acarinina pentacamerata (Subbotina)

Globorotalia pentacamerata Subbotina, 1947, p. 128-129, pl. 7, figs. $12-17$, pl. 9, figs. 24-26.

Acarinina wilcoxensis (Cushman and Ponton)

Nonion wilcoxensis Cushman and Ponton, 1932, p. 64, pl. 8, fig. 11.

Chiloguembelina cubensis (Palmer)

Guembelina cubensis Palmer, 1934, p. 74, figs. 1-6.

Candeina nitida d'Orbigny Candeina nitida d'Orbigny, 1839, p. 108, pl. 2, figs. 27-28.

Dentoglobigerina galavisi (Bermudez) Globigerina galavisi Bermudez, 1960, p. 1183, pl. 4, fig. 3.

Globigerina ampliapertura Bolli Globigerina ampliapertura Bolli, 1957b, p. 108, pl 22, figs. 4-7.

Globigerina bulloides d'Orbigny Globigerina bulloides d'Orbigny, 1826, p. 277, mod. no. 76.

Globigerina higginsi (Bolli) Globigerinoides higginsi Bolli, 1957c, p. 164, pl. 36, figs. 11-13

Globigerina nepenthes Todd Globigerina nepenthes Todd, 1957, p. 301, pl. 78, fig. 7.

Globigerina taroubaensis Brönnimann Globigerina taroubaensis Brönnimann, 1952, p. 67, pl. 2, figs. 1618.

Globigerina tapuriensis Blow and Banner

Globigerina tripartita tapuriensis Blow and Banner, 1962, p. 9798 , pl. 10, figs. h-k.

Globigerina tripartita Koch Globigerina bulloides d'Orbigny var. tripartita Koch, 1926, p. 746, fig. $21 \mathrm{a}-\mathrm{b}$.

Globigerinatheka index (Finlay)

Globigerinoides index Finlay, 1939, p. 125, pl. 14, figs. 85-88.

Globigerinatheka (Porticulasphaera) kugleri (Bolli, Loeblich, and Tappan)

Globigerapsis kugleri Bolli, Loeblich, and Tappan, 1957, p. 34, pl. 6 , figs. $6 \mathrm{a}-\mathrm{c}$.

Globigerinatheka (Porticulasphaera) mexicana (Cushman) Globigerina mexicana Cushman, 1925b, p. 6, pl. 1, fig. 8 .

Globigerinatheka (Porticulasphaera) semiinvoluta (Keijzer) Globigerinoides semiinvolutus Keijzer, 1945, p. 206pl. 4, fig. 58.

Globigerinoides parkerae Bermudez

Globigerinoides parkerae Bermudez, 1960, p. 232, pl. 10, figs. 10,11 .

\footnotetext{
${ }^{3}$ Additional paleontological references not cited in Stainforth et al. (1975):

Mallory, V.S., 1959. Lower Tertiary biostratigraphy of the California Coast Ranges: Tulsa (Am. Assoc. Pet. Geol.).

Palmer, D.K., 1934. The foraminiferal genus Guembelina in the Tertiary of Cuba. Mem. Soc. Cubana Hist. Natural, 8:73-76.

Ehrenberg, C.G., 1861. Elemente des tiefen Meeresgrundes im Mexikanischen Golf Strome bei Florida; Uber die Tiefgrund-Verhaltnisse Des Oceans am Eingange der Davisstrasse und bei Island. K. Preuss. Akad. Wiss., Berlin, Monatsber., Berlin, Deutschland, 276, 277, 303.
} 
Globigerinoides ruber (d'Orbigny)

Globigerina rubra d'Orbigny, 1839, p. 82-83, pl. 4, figs. 12-14.

Globigerinoides sacculifer (Brady)

Globigerina sacculifer Brady, 1877, p. 535, based on figure of Globigerina helcina Carpenter (not d'Orbigny) 1862, pl. 12, fig. 11 .

Globorotalia crassaformis (Galloway and Wissler)

Globigerina crassaformis Galloway and Wissler, 1927, p. 41, pl. 7, fig. 12.

Globorotalia juani Bermudez and Bolli

Globorotalia hirsuta (d'Orbigny) Colalongo and Sartoni, 1967, p. 267 , pl. 31 , fig. 5 .

Globorotalia inflata (d'Orbigny)

Globigerina inflata d'Orbigny, in Barker-Webb and Berthelot, 1839, p. 134, pl. 2, figs. 7-9.

Globorotalia margaritae Bolli and Bermudez

Globorotalia hirsuta (d'Orbigny), AGIP Mineralia, 1957, pl. 48, fig. 4.

Globorotalia menardii (Parker, Jones and Brady, 1865) ex d'Orbigny Rotalia (Rotalie) menardii d'Orbigny, 1826. p. 273 (nomen nudum)

Globorotalia merotumida Blow and Banner

Globorotalia merotumida Blow and Banner (in Banner and Blow, 1965 c), p. 1352 , figs. la-c.

Globorotalia miocenica Palmer

Globorotalia menardii miocenica Palmer, 1945, p. 70-71, pl. 1, fig. 10.

Globorotalia plesiotumida Blow and Banner

Globorotalia (Globorotalia) tumida plesiotumida Blow and Banner in Banner and Blow, 1965c, p. 1353, fig. 2.

Globorotalia praemiocenica Lamb and Beard

Globorotalia (Globorotalia) cultrata limbata (Fornasini, 1902) (part), Blow 1969, (not Fornasini), p. 359, pl. 42, figs. 2-3, (not pl. 7, figs. 4-6.

Globorotalia puncticulata (Deshayes)

Globigerina punctulata d'Orbigny, 1826, p. 277, (nomen nudum).

Globorotalia tumida (Brady)

Pulvinulina menardii tumida Brady, 1877, p. 535.

Globoquadrina altispira globosa Bolli

Globoquadrina altispira globosa Bolli, 1957b, p. 111, pl. 24, figs. 9-10.

Globoquadrina dehiscens (Chapman, Parr and Collins)

Globorotalia dehiscens Chapman, Parr and Collins, 1934, p. 569, pl. 11 , fig. 6.

Hantkenina alabamensis Cushman

Hantkenina alabamensis Cushman, 1925a, p. 3, fig. 1, pl. 1, figs. $1-6$, pl. 2, fig. 5 .

Morozovella aequa (Cushman and Renz)

Globorotalia crassata (Cushman) var. aequa Cushman and Renz, 1942 , p. 12 , pl. 3, fig. 3 .

Morozovella aragonensis (Nuttall)

Globorotalia aragonensis Nuttall, 1930, p. 288, pl. 24, figs. 6-11.

Morozovella caucasica (Glaessner)

Globorotalia aragonensis Nuttall var. caucasica Glaessner, 1937a, p. 31, pl. 1, fig. 6 .

Morozovella formosa gracilis (Bolli)

Globorotalia formosa gracilis Bolli, 1957a, p. 75, pl. 18, figs. 4-6.

Morozovella lehneri (Cushman and Jarvis)

Globorotalia lehneri Cushman and Jarvis, 1929, p. 17, pl. 3, fig. 16.

Morozovella lensiformis (Subbotina)

Globorotalia lensiformis Subbotina, 1953, p. 214, pl. 18, figs. 4-5.

Morozovella marginodentata (Subbotina)

Globorotalia marginodentata Subotina, 1953, p. 212-213, pl.17.

figs. 14-16, pl. 18, figs. 1-3.

Morozovella spinulosa (Cushman)

Globorotalia spinulosa Cushman, 1927, p. 114, pl. 23, fig. 4.

Morozovella subbotinae (Morozova)

Globorotalia subbotinae Morozova, 1939, p. 80-81, pl. 2, fig. 16.

Muricoglobigerina senni (Beckmann)

Sphaeroidinella senni Beckmann, 1953, p. 394-395, fig. 20, pl. 26, figs. 2-4.

Muricoglobigerina soldadoensis soldadoensis Brönnimann

Globigerina soldadoensis Brönnimann, 1952c, p. 7, p. 9, pl. 1, figs. 1-9.

Muricoglobigerina soldadoensis angulosa (Bolli)

Globigerina soldadoensis angulosa Bolli, 1957a, p. 71, pl. 16, figs. 4-6.
Neogloboquadrina acostaensis (Blow)

Globorotalia acostaensis Blow, 1959, p. 208, pl. 17, fig. 106.

Neogloboquadrina atlantica (Berggren)

Globigerina atlantica Berggren, 1972b, p. 972, pl. 1, figs. 1-7.

Neogloboquadrina continuosa (Blow)

Globorotalia opima Bolli var. continuosa Blow, 1957, p. 119, pl. 29, figs. 2a-c.

Neogloboquadrina humerosa (Takayanagi and Saito) Globorotalia humerosa Takayanagi and Saito, 1962, p. 78, pl. 28 , figs. 1-2.

Neogloboquadrina pachyderma (Ehrenberg) Aristerospira pachyderma Ehrenberg, 1861, p. 276, p. 277, p. 303: 1872 , pl. 1, fig. 4.

Orbulina bilobata (d'Orbigny) Globigerina bilobata d'Orbigny, 1846, p. 164, pl. 9, figs. 11-14.

Orbulina suturalis Brönnimann Orbulina suturalis Brönnimann, 1951, p. 135, figs. 15,16,20.

Orbulina universa d'Orbigny Orbulina universa d'Orbigny, 1839, p. 2, pl. 1, fig. 1.

Pseudohastigerina micra (Cole) Nonion micrus Cole, 1927, p. 22, pl. 5, fig. 12.

Pulleniatina obliquiloculata (Parker and Jones) Pullenia sphaeroides d'Orbigny var. obliquiloculata Parker and Jones, 1865 , p. 365 , p. 368 , pl. 19 , figs. $4 a-b$.

Sphaeroidinella dehiscens (Parker and Jones) Sphaeroidina bulloides dehiscens Parker and Jones, 1865, p. 369, pl. 19, fig. 5 .

Sphaeroidinellopsis subdehiscens (Blow)

Sphaeroidinella dehiscens subdehiscens Blow, 1959, p. 195, pl. 12, figs. 71-72.

Subbotina angiporoides (Hornibrook) Globigerina angipora Hornibriook, 1965, p. 834-838, figs. 1-2.

Subbotina frontosa (Subbotina) Globigerina frontosa Subbotina, 1953, p. 84, pl. 12, figs. 3-7.

Subbotina linaperta (Finlay) Globigerina linaperta Finlay, 1939c, p. 125, pl. 13, figs. 54-56.

Subbotina triloculinoides (Plummer) Globigerina triloculinoides Plummer, 1926, p. 134, pl. 8, fig. 10.

Truncorotalia tosaensis (Takayanagi and Saito) Globorotalia tosaensis Takayanagi and Saito, 1962, p. 81-82, pl. 28 , figs. $11-12$.

Truncorotalia truncatulinoides (d'Orbigny) Rotalina truncatulinoides d'Orbigny, 1839, p. 132, pl. 2, figs. 2527.

Truncorotaloides quetra (Bolli) Globorotalia quetra Bolli, 1957a, p. 79-80, pl. 19, figs. 1-6.

Truncorotaloides rohri Brönnimann and Bermudez Truncorotaloides rohri Brönnimann and Bermudez, 1953, p. 818819 , pl. 87, figs. $7-9$.

Truncorotaloides topilensis praetopilensis Blow Truncorotaloides topilensis praetopilensis Blow, 1979, p. 1093, pl. 155 , fig. 9, pl. 169 , figs. $1-9$, pl. 178 , figs. $6-9$, pl. 185 , figs. $7-8$, pl. 187 , figs. $1-4$, pl. 203 , figs. $1-2$, pl. 207 , figs. $1,2,5,6$, pl. 208 , figs. 1-6.

Truncorotaloides topilensis topilensis (Cushman) Globigerina topilensis Cushman, 1925b, p. 7, pl. 1, fig. 9.

Turborotalia cerroazulensis cerroazulensis (Cole) Globigerina cerro-azulensis Cole, 1928, p. 17, pl. 1, figs. 11-13.

Turborotalia cerroazulensis cocoaensis (Cushman) Globorotalia cocoaensis Cushman, 1928, p. 75, pl. 10, fig. 3 .

Turborotalia cerroazulensis cunialensis (Toumarkine and Bolli) Globorotalia cerroazulensis cunialensis Toumarkine and Bolli, 1970, p. $144-145$, pl. 1 , figs. $37-39$, pl. 2 , fig. 10.

Turborotalia cerroazulensis pomeroli (Toumarkine and Bolli) Globorotalia cerroazulensis pomeroli Toumarkine and Bolli, 1970, p. 140-144, pl. 1., figs. 10-18, pl. 2, figs, 1-2.

Turborotalia cerroazulensis possagnoensis (Toumarkine and Bolli) Globorotalia cerroazulensis possagnoensis Toumarkine and Bolli, 1970 , p. $139-140$, pl. 1, figs. 4-9.

Turborotalia chapmani (Parr) Globorotalia chapmani Parr, 1938, p. 87, pl. 9, figs. 8-9.

Turborotalia increbescens (Bandy) Globigerina increbescens Bandy, 1949, 120, pl. 23. fig. 3.

Turborotalia kugleri (Bolli) Globorotalia kugleri Bolli, 1957b, p. 118, pl. 28, figs 5-6. 